\title{
PROBLEMS FACED BY THE PASSENGERS IN SOUTHERN RAILWAYS WITH SPECIAL REFERENCE TO ERODE CITY
}

\author{
D. Anbupriya ${ }^{1}$ and S. Subadra ${ }^{2}$ \\ ${ }^{1}$ Department of Commerce, Kongu Arts and Science College, India \\ ${ }^{2}$ Department of Commerce, N.K.R. Government Arts College for Women, India
}

\begin{abstract}
Trains are perhaps the most reliable form of transport. They are not only cheap but are also very convenient for long distances. Everyday hundreds of commuters board the trains to reach various destinations. Some people even consider them to be a blessing given the increasing frequency in the number of traffic jams. However, this efficient system of transportation too has some disadvantages. This study deals the problems faced by the passengers while travelling in train and at stations. The findings of the study revealed that poor toilet maintenance and late arrival of train are causing inconveniences to the public. The study concludes that Indian Railway has to take steps to set right the passengers' inconvenience.
\end{abstract}

Keywords:

Passengers, Railways, Passengers' Inconvenience, Public, Transportation

\section{INTRODUCTION}

With the quickening pace of modernization, the Railway travelers today expect much more from the system than the railways did in the past in the form of amenities. The provision of passenger amenities is, therefore, one of the important objectives of the Indian Railways both as a business ethic and as a social obligation [7]. The Indian Railways has issued a Citizens' Charter on Passenger services in which, it has been pledged to ensure adequate passenger amenities in trains and at Railway stations. One of the thrust areas in the $8^{\text {th }}$ plan was to provide basic passenger amenities at all stations on a priority basis [8]. The introduction of economic liberalization in July 1991 threw a major challenge before the Indian Railways. As a result special emphasis was laid on customer care and user-friendly services. This article deals with the problems faced by the passengers in Southern Railways [9].

\subsection{INDIAN RAILWAYS}

Indian Railways are the most important means of transport in India. In developing country like India, Rail transport plays a vital role in economic development and industrial development. Indian Railways not only provides passenger services but also the freight services around the nation. They also transport large and heavy materials like cement, coal, iron-ore, petroleum, food grains and jute.

The railway network of India has brought together the whole of country, thus creating a feeling of unity among the Indians. The Indian Railways network connects the social, cultural, and economical fabric of the country and covers whole of the country ranging from North to South and East to West removing the distance barrier for the people. Indian Railways has helped the economic life of the country and helped in accelerating the development of industry and agriculture.

\subsection{STATEMENT OF THE PROBLEM}

Among the various modes of transport, Railways is one of the biggest modes of passenger transport in the world. Indian Railways face more competitive threats from airlines, luxury buses, public transports, and personalized transports. Though there are competitions from various mode of transport, Indian Railways has its unique features and provide more services to the passengers [10]. With the increase of technological advancements, Indian Railways have started to use the latest technology for making the service delivery process more efficient. In order to satisfy the passengers, the Indian Railways provides various services to its passengers [11]. But, the passengers face some problems. Hence, the researcher in this study has made an attempt to answer the question "What are the problems faced by the passengers while travelling by train, at station and on board?"

\subsection{OBJECTIVES OF THE STUDY}

- To identify the problems faced by the passengers while travelling by train, at station and on board.

- To offer suggestions based on the findings of the study.

\subsection{HYPOTHESES OF THE STUDY}

The passengers are not facing any problems at the railway stations and at the time of travelling in the train.

\section{LITERATURE REVIEW}

Rao and Ramlal [1] emphasized that the geographic, cultural, environmental, social, economical environment and quality of service like nature of vehicle, journey time, speed of the vehicle, disturbance, comforts, terminal services, frequencies of trips are influenced by the passengers' perception in travel behaviour. They also found that various qualitative factors like time and cost factors; frequency and reliability of service, comforts and convenience have a major role in making choice among available alternative modes.

Ning [2] analyzed the level of closeness of railways to the life of people in Japan. It is suggested that railways has to offer the communities quick accessibility to shopping, entertainment, information, cultural activities, and community services along with safe, timely and speedy transportation to improve the passenger satisfaction.

Sekaran [3] made a study of public complaints in Southern Railway, which revealed that the highest number of complaints 
has been about punctuality of trains. He made certain suggestions to minimize delays in running of trains to drivers, guards, and station staff. He also suggested forming a Complaint Research and Public Grievance Cell directly reporting to the Minister to be set up at the national level.

Durgamani et al. [4] measured the facilities provided to the passengers' right from ticket booking to the on-board travel experience in the trains and also the problems between the passengers and railway administration. This study has identified the actual determinants of customer satisfaction with quality of service provided on railway platforms and suggested certain policy implications for Indian Railways. Finally, the study offered suggestions for railway administration whereby areas for improving services may be identified and user (passenger) satisfaction, specifically on railway platforms, may be enhanced at the Kumbakonam Junction.

Rajeshwari and Elangovan [7] highlights the problems faced by the passengers while reserving tickets, on boarding the train and while travelling in the train in Salem Division of Southern Railway Zone. A sample of 500 passengers is drawn by using stratified random sampling technique from the major junctions of Salem Division of Southern Railway Zone. They suggested that the Railway Police Force could be strengthened to improve the security of the passengers and better infrastructures can be introduced to avoid congestion in the stations and railway ticket reservation facilities can also be improved.

Sheeba and Kumuthadevi [5] analyzed about the passengers' satisfaction and service quality of Southern Railways. Based on the analysis of their study, it was found out that Amenities provided the railways presently in trains are not at all satisfied by the passengers. They are concluded that the Railways try to improve the core areas and deliver quality of services to the passengers. This attempt from the part of railways will definitely retain the passengers in enjoying its services in future.

Premsanthi and Sivakami [6] identify the train passengers' satisfaction and problems of ticket reservation in erode district. The study highlights the Satisfaction and problems faced by the passengers while reserving 105 passengers is drawn using stratified random sampling technique used for chi square analysis is the tool used to analyses the Satisfaction and problems faced by the passengers. They are suggested that the Passengers require more reservation and enquiry counters and they also in need of area wise service to book their tickets.

\section{RESEARCH METHODOLOGY}

The primary data was used to collect information from public or passenger of the Erode city. A well-structured questionnaire is used to collect data for the study. The secondary data was also used to collect the information from Erode passenger reservation center, published articles and miscellaneous reports. A questionnaire was designed covering the whole railway reservation system. Stratified random sampling method has been followed, 400 questionnaires were prepared and distributed to the respondents. The primary data were collected from April $2017-$ June 2017 with the help of questionnaires. The Friedman test is used to identify the problems faced at railway stations and travelling in train.

\section{ANALYSIS AND INTREPRETATIONS}

\subsection{DEMOGRAPHIC PROFILE OF THE RESPONDENTS}

The demographic characteristics of the respondents such as age, gender, educational qualification and occupation were studied with the help of simple percentage analysis.

Table.1. Classification of the respondents based on personal factors

\begin{tabular}{|c|c|c|c|c|}
\hline S.No. & \multicolumn{2}{|c|}{ Personal Factors } & Frequency & Percentage \\
\hline \multirow{4}{*}{1} & \multirow{4}{*}{ Age } & Below 30 years & 254 & 63.5 \\
\hline & & $30-45$ years & 103 & 25.8 \\
\hline & & $45-60$ years & 32 & 8.0 \\
\hline & & Above 60 years & 11 & 2.7 \\
\hline \multirow{2}{*}{2} & \multirow{2}{*}{ Gender } & Male & 205 & 51 \\
\hline & & Female & 195 & 49 \\
\hline \multirow{5}{*}{3} & \multirow{5}{*}{$\begin{array}{l}\text { Educational } \\
\text { Qualification }\end{array}$} & $\begin{array}{l}\text { No formal } \\
\text { education }\end{array}$ & 7 & 1.8 \\
\hline & & School level & 54 & 13.5 \\
\hline & & College level & 219 & 54.7 \\
\hline & & $\begin{array}{l}\text { Professional } \\
\text { qualification }\end{array}$ & 115 & 28.7 \\
\hline & & Others & 5 & 1.3 \\
\hline \multirow{6}{*}{4} & \multirow{6}{*}{ Occupation } & $\begin{array}{l}\text { Private } \\
\text { employees }\end{array}$ & 131 & 32.8 \\
\hline & & $\begin{array}{c}\text { Government } \\
\text { employees }\end{array}$ & 113 & 28.2 \\
\hline & & Professional & 60 & 15.0 \\
\hline & & Businessmen & 34 & 8.5 \\
\hline & & Housewives & 60 & 15.0 \\
\hline & & Others & 2 & 0.5 \\
\hline \multicolumn{3}{|c|}{ Total } & 400 & 100.00 \\
\hline
\end{tabular}

The Table. 1 shows the distribution of respondents on the basis of their demographic profile. It is observed from the Table.1, that out of 400 respondents, 205 are male which is $51 \%$ and the remaining 195 are female which forms $49 \%$ of the sample respondents. It is evident that in the sample surveyed majority of the respondents are male.

It is observed from the age wise classification of the respondents, out of 400 total respondents $63.5 \%$ are in the age group of below 30 years, $25.8 \%$ fall in the age group of 30-45 years, $8 \%$ are between $45-60$ years and the remaining $2.7 \%$ are above 60 years of age. To summarise, maximum respondents are belonging to the age group of below 30 years old.

The educational qualification of the respondents is concerned, $54.7 \%$ of them have college level education, $28.7 \%$ are professionals, $13.5 \%$ have school level education, $1.8 \%$ of the respondents has no formal education and considered as illiterates and $1.3 \%$ of the respondents belong to other categories such as diploma and other certificate courses. It is understood that the majority of the respondents are having college level education. 
As per the occupation wise classification of the respondents, It is observed that out of 400 respondents, $32.8 \%$ are Private employees, $28.2 \%$ are Government employees, $15 \%$ are professionals, $15 \%$ are housewives, $8.5 \%$ are businessmen and the remaining $0.5 \%$ belong to other categories such as agriculturists and retired persons. It is clearly known that the majority of the respondents are private sector employees.

\subsection{PROBLEMS FACED AT RAILWAY STATIONS}

Now a day, the passengers expect quality in their journey and passengers desire to enjoy a relatively better quality or availing superior quality services. But passengers faced many problems while travelling in train and at stations. If the Indian Railways properly assess the problems and inconveniences of the passengers and deliver the service according to their expectation, it will be the most profitable public sector undertaking in India. With this perspective, the Friedman test is used to identify the problems faced at railway stations and travelling in train.

Null Hypothesis: The passengers are not facing any problem at the Railway stations in the study area.

Table.2. Friedman test for the problems faced at railway stations

\begin{tabular}{|c|c|c|c|}
\hline Statements & $\begin{array}{l}\text { Mean } \\
\text { Rank }\end{array}$ & $\begin{array}{l}\text { Chi- } \\
\text { square } \\
\text { value }\end{array}$ & $P$ value \\
\hline Late arrival of train & 10.16 & \multirow{17}{*}{224.394} & \multirow{17}{*}{$0.000^{*}$} \\
\hline Inadequate ticket counters & 8.87 & & \\
\hline $\begin{array}{c}\text { Problem due to beggars and } \\
\text { vendors }\end{array}$ & 9.42 & & \\
\hline Poor sanitary conditions & 9.74 & & \\
\hline Poor response to enquiry & 8.53 & & \\
\hline Poor catering facility & 8.84 & & \\
\hline Poor lighting facility & 8.61 & & \\
\hline Inadequate announcement & 7.97 & & \\
\hline Theft & 10.10 & & \\
\hline Non availability of tickets & 8.89 & & \\
\hline Long queue & 9.69 & & \\
\hline Poor response of staff members & 8.46 & & \\
\hline Slow issue of tickets & 8.57 & & \\
\hline $\begin{array}{l}\text { Frequent repairs in the } \\
\text { computer }\end{array}$ & 8.42 & & \\
\hline Inadequate staff members & 8.08 & & \\
\hline Inadequate water facilities & 9.18 & & \\
\hline Bulk booking by travel agents & 9.48 & & \\
\hline
\end{tabular}

The Table. 2 highlights the results of Friedman test for the problems faced by the passengers at the railway stations in the study area. It is identified from the Table.2, the calculated chisquare value is 224.394 and corresponding $\mathrm{p}$ value is 0.000 which is less than 0.01 and it is statistically significant. Hence, it is concluded that passengers are facing various problems, of which late arrival of train is the most significant problem the respondents face at railway stations during the time of train travelling in the study area.

\subsection{PROBLEMS FACED WHILE TRAVELLING IN THE TRAIN}

Null Hypothesis: There are no major problems faced by the passengers while travelling in the train in the study area.

Table.3. Friedman Test for the problems faced while travelling in the train

\begin{tabular}{|c|c|c|c|}
\hline Major Problem & Mean Rank & $\begin{array}{l}\text { Chi- } \\
\text { square } \\
\text { value }\end{array}$ & $p$ value \\
\hline Behavior of the staff & 4.37 & \multirow{8}{*}{109.066} & \multirow{8}{*}{$0.000 * *$} \\
\hline $\begin{array}{c}\text { Poor maintenance of } \\
\text { toilet }\end{array}$ & 5.12 & & \\
\hline Transgender menace & 4.20 & & \\
\hline Beggars menace & 4.64 & & \\
\hline $\begin{array}{l}\text { Poor condition of } \\
\text { electrical appliances }\end{array}$ & 4.32 & & \\
\hline Inadequate security & 4.45 & & \\
\hline $\begin{array}{l}\text { Inadequate service } \\
\text { personnel in the } \\
\text { compartments }\end{array}$ & 4.06 & & \\
\hline Insect menace & 4.84 & & \\
\hline
\end{tabular}

Friedman test is used to find whether there is any major problem faced by the passengers at the time of travel in the train. The study indicated that the calculated chi-square value is 109.066 and $p$ value is 0.000 which is less than 0.01 . Therefore, the null hypothesis is rejected at $1 \%$ level of significance. Therefore, it could be concluded that passengers are facing various problems during their travel in the train. Hence, it is concluded that passengers are facing various problems, of which poor maintenance of toilet is the most significant problem the respondents face during their journey.

\section{FINDINGS}

- The passengers are facing various problems, of which late arrival of train is the most significant problem the respondents face at railway stations during the time of train travelling in the study area.

- Passengers are facing various problems, of which poor maintenance of toilet is the most significant problem the respondents face during their journey.

\section{SUGGESTIONS}

- It's hardly any train nowadays which runs bang on schedule. Valuing time is a concept lost on Indians sometimes, this is the biggest problem Indian Railway has to solve. It would be really nice if the train was more punctual, and would save precious time and money. Hence effective monitoring mechanism should be implemented to avoid delayed arrival of trains in respective stations.

- Ever carried toiletries, hand-wash or hand sanitizer in one of the problem while travelling in train. Indian Railway have to 
improve greatly by introducing toiletries, bidets, and biotoilets in upper classes, but to have a vision of a Clean India, this needs to be done for all classes of travel.

- Railways highlighting their menu along with prices merely shed a light on the state of things. Hopefully, with the handover of catering to IRCTC, and more e-catering options, food will become a part of train journeys people enjoy, rather than dread. The Indian railway has been on the backbench when it comes to quality food served in the long distance trains.

- Railways should plan to affix security cameras inside the train to avoid unscrupulous persons entering into the train during the travel hours.

\section{CONCLUSION}

The Indian railway is also among the world's top commercial setup, which has more than 15 lakhs regular employees plus millions depending upon it. Although the development of railways in our country took place rapidly, still there are numberless problems in the path of steady growth. The main problems have been analyzed and it is concluded Indian Railways need a lot to improve the overall services including passenger safety, convenience and running on time. If the suggestive measurements have been considered by the Indian Railways, it is assured that the Indian Railways will shine and bring grandeur to our country in the near future.

\section{REFERENCE}

[1] Panduranga Rao and B. Ramlal, "Factors Influencing the Transport Behaviour of Man", Journal of Transport Management, pp. 15-21, 1984.

[2] Zhang Ning, "A Railway Service close to People's Lives", Japan Railway and Transport Review, Vol. 11, No. 4, pp. 25-37, 1996.
[3] P. Sekaran, "Public Complaints in Southern Railway", Ph.D Dissertation, Madras University, 2006.

[4] M.K. Durgamani, R. Renuka and M. Ganesan, "A Study on Passenger Satisfaction in Train Travel with Special reference to Kumbakonam Station in Tamil Nadu", Indian Journal of Applied Research, Vol. 3, No. 4, pp. 333-335, 2013.

[5] A. Sheeba and K. Kumuthadevi, "Service Quality of Southern Railways Satisfaction on Facilities: Kerala Passengers Perspective", International Journal of Business and Management Invention, Vol. 4, No. 10, pp. 29-33, 2015.

[6] P. Premsanthi and M.Sivakami, "A Study on Train Passengers Satisfaction and problems of Ticket Reservation in Erode District", International Journal of Innovative Research in Management Studies, Vol. 1, No. 10, pp. 72-78, 2016.

[7] G. Rajeshwari and D. Elangovan, "Problems Faced by the Passengers of Indian Railways-A Study in Salem Division of Southern Railway Zone", Global Journal of Commerce and Management Perspective, Vol. 3, No. 4, pp. 196-200, 2014.

[8] Kokku Randheer, Ahmed A. AL-Motawa and J. Prince Vijay, "Measuring Commuters Perception on Service Quality using SERVQUAL in Public Transportation", International Journal of Marketing Studies, Vol. 3, No. 1, pp. 21-34, 2011.

[9] G. Raghuram and Rachna Gangwar, "Marketing Strategies for Freight Traffic on Indian Railways-A Systems Perspective", Technical Report, Indian Institute of Management, Ahmedabad, pp. 1-23, 2007.

[10] Lauren J. Thomas, Daniel J.A. Rhind and Katie J. Robinson, "Rail Passenger Perceptions of Risk and Safety and Priorities for Improvement", Cognition, Technology and Work, Vol. 8, No. 1, pp. 67-75, 2006.

[11] Patel Hasmukh, "Improving Railway Security through Public Participation", Management in Government, Vol. 38, No. 4, pp. 43-57, 2007. 